\title{
ETHNIC OCCUPATIONAL STATUSES
}

\section{Lewis A. Mennerick \\ University of Kansas}

As Everett C. Hughes has pointed out, every status, including occupational statuses, has both specifically determining traits and "auxiliary traits which have come to be expected of its incumbents".1 The determining trait of the physician, for example, is the license to practice medicine. However, physicians in the United States are also expected to be white, male, Protestant, and of "American" stock. In this paper, we extend the concept of "auxiliary traits" and use it to distinguish between general occupational statuses and ethnic occupational statuses. Furthermore, we explore some of the career alternatives open to ethnic individuals, stressing the consequences of occupying an ethnic occupational status. Finally, we discuss the relevance of the status as a situational determinant of behavior.

\section{Ethnic Occupational Statuses}

The concept of "ethnic occupational status" does not refer to occupations found only among certain ethnic groups. Rather, ethnic occupational statuses are a special type of general occupational statuses. They differ from general occupational statuses to the extent that they have auxiliary ethnic traits which a particular ethnic group has come to expect of the status incumbents. These incumbents do not abandon ethnic group values. 2 Rather, they strive to possess not only the specifically determining traits but also the auxiliary traits which their ethnic group associates with the occupation: auxiliary traits which are more or less unique to that particular ethnic group, which presumably reflect ethnic group values, and which must be displayed if the status incumbents are to function successfully within the ethnic community.

However, not all occupational statuses have an ethnic counterpart Chemists, engineers, and skilled laborers, for example, usually do not seek to possess and display auxiliary ethnic traits. While ItalianAmericans may occupy the status of chemist, they are not usually 
thought of as "Italian chemists." Auxiliary ethnic traits are simply not relevant in these particular work worlds. However, Italian-Americans who of physician may come to be thought of as "Italian doctors". And as these individuals apply such ethnic occupational labels to themselves, they learn who they are and how they ought tional labels to themselves, they learn who they are individuals occupying such other statuses as union labor leader, politician, musician, lawyer, and newspaper editor. Regardless of the divergence in degree of involvement among these occupations, they often come to possess auxiliary ethnic traits. This can be largely explained by examining the important characteristics which these occupational statuses share.

1. They are service occupations: that is, occupations in which the status incumbent provides services more or less directly for the client, thus allowing the client to direct or at least attempt to direct the tasks of the worker. 4 Likewise, the status incumbent has the potential power to affect certain aspects of the client's life in a manner favorable or unfavorable to the client.

2. They are "public" statuses, highly visible at least to the client, if not always to the entire community.

3 . They are statuses which require either advanced education or special talents and thus which cannot be occupied by most members of the community.

4. Finally, in spite of and because of the preceding status characteristics, the status incumbent is dependent upon support from the community in order to fulfill the accompanying role expectations.

Accordingly, these statuses are highly vulnerable to having auxiliary ethnic traits attached to them by ethnic group members. Therefore, when we refer to ethnic occupations or occupational statuses in this paper, we are referring specifically to ethnic service occupations.

The country musician will serve as an example of an ethnic occupational status. The determining trait of the musician in general is that he possess certain auxiliary traits. Thus, he is expected to be humble, sincere, and generally grateful to "the folks" who have made his success possible, even though he may be greatly differentiated from these people in terms of income, talent, and general style of living. The country musician has risen from "the soil" - from the level of the common working man - without giving up his family and old friends: his heritage. And it is with this "buddy image" that members of the ethnic community identify. 5

Thus, the occupational status of musician becomes an ethnic occupational status when ethnic auxiliary traits come to be associated with it. This is not to say that all southern musicians occupy ethnic occupational statuses. However, those who play country music and who fulfill the accompanying auxiliary expectations of the ethnic group are incumbents of such a status. And as ethnic group members and potential ethnic occupational status incumbents, they are presented with career alternatives and potential behavioral constraints which out-group members do not experience.

\section{Alternatives and Consequences}

Unlike out-group members, ethnic individuals have four basic career alternatives open to them: 1 . They may attempt to shed their ethnic traits and compete on the open market. 62 . They may retain their traits and attempt to compete on the open market. 7 . They may retain their ethnic traits and work to raise the general level of prestige of their ethnic group and thus raise the level of their own position. 8 . They may simply remain within the ethnic community and retain their auxiliary ethnic traits according to the expectations of the community. It is those ethnic individuals who choose the fourth alternative who occupy what we have defined as ethnic occupational statuses.

While the specific content of auxiliary ethnic traits varies among different occupations and among different ethnic groups, several phenomena stand out. Due to the unique character of the ethnic occupational status, the status incumbent serves functions and is confronted with problems which are alien to the non-ethnic incumbent of the general occupational status. Thus, in what follows, we shall explore the ethnic occupational status; emphasizing the status incumbent's lack of job alternatives, his function as a "symbolic representative of the people", the potential conflict inherent in his status, and the relevance of his status as a situational determinant of behavior. For the purpose of illustration, we shall concentrate on the occupational statuses of physician (general practitioner), union labor leader, politician, and musician.

Lack of job alternatives: The ethnic individual who retains the auxiliary ethnic traits associated with his occupational status is often limited in job alternatives. In fact, he may strive to continue to occupy his ethnic occupational status primarily because his qualifications are not strong enough to enable him to compete outside of the ethnic community or because his participation in the larger system is restricted by out-group persons who are in positions of power. Greer points out, for example, that Mexicans (and Negroes) tend to occupy low status jobs. Thus, those ethnic individuals who become union leaders are more limited in their job alternatives. In contrast to other leaders, "Their function is likely to be specialized to union work and to a particular union at that".9 Lacking a negotiable skill, they are placed in a particularly precarious position. 
Like ethnic union officials, many country musicians have risen from relatively low status, non-musician jobs. And as musicians, most are restricted in their occupational alternatives. Due to the lack of versatility, they usually cannot play other forms of music well enough to compete successfully.

Likewise, ethnic politicians and doctors may not be able or be allowed to compete successfully on the larger market. ${ }^{10}$ Thus, they may be constrained to remain within the community. And if they do not fulfill the auxiliary traits which have come to be associated with their respective statuses within the ethnic group - if, for example, the physician moves out of the ghetto or the politician fails to speak on behalf of the people - they may be labeled as "sell-outs" and may thus lose the support of the community. Within the ethnic community, their position is relatively secure, and their prestige is relatively high. However, to attempt to go outside on their own, without the support of the ethnic community, involves a big gamble. It is a risk which usually must be taken if they are to rise appreciably above their present status. When the competition on the open market is more rigorous the gamble may result in disaster. Not only may they not attain a higher status, but indeed they may loose their present position.

Representative of "The People": The ethnic individual, who by choice or constraint occupies an ethnic occupational status, is expected to provide various services for ethnic group members, but to provide them according to the group's expectational standards. As previously mentioned, these statuses possess certain unique qualities in relation to other statuses in their respective social systems. Especially since his position is visible and endowed both with special skills and with more than ordinary power, the status incumbent must both identify with the community and present himself in such a manner so as to allow the community to identify with him. Thus, he must possess the auxiliary status traits which the community has attached to his occupational status and which presumably reflect community values. And as such, he can be viewed as a symbolic representative of his ethnic group. He may be elected as in the cases of the politician and union leader or his position may be implied as in the cases of the physician and country musician. But none the less, he serves to personify group values: the community's "way of doing things." As a symbolic representative, the status incumbent is placed in a very precarious position. If his "performance" falters during the course of his career, the accompanying power may be withdrawn and delegated to others who come closer to fulfilling community expectations or even to more prestigious out-group status incumbents.

The country musician serves as a symbolic representative of an ethnic group generally composed of southern and/or rural working-class people. As such, he is expected to maintain his allegiance to that form of music and his respect for the southern, rural mode of life - and its lingering Gemeinschaft values - out of which the music emerged and with which most of his fans identify.

An example of the ethnic politician as a symbolic representative is found in the description of a Puerto Rican candidate for the New York City Council in 1957.11 The candidate, a crusading newspaper reporter for El Diario de Nuevo York, based his campaign on the issue of the lack of Puerto Rican representation in the city government. More specifically, he emphasized the terrible conditions under which Puerto Ricans were forced to live, the manner in which they were being exploited through fear and ignorance, and the fact that neither of his opponents spoke Spanish. The candidate's role as a symbolic representative was reflected in his campaign slogans: "De Boricua ...A Boricua" ("From a Puerto Rican ... To a Puerto Rican") and "Y los últimos serán los primeros..." ("And the last shall be first...").

The case of the ethnic labor leader is illustrated in the account of the career of an Italian organizer. Joe Piscitello has much in common with the Italians he sought to organize. He quit school at the age of twelve and went to work for $\$ 1.50$ per week. Through the years he became active in union affairs and has been extremely effective "... because the people in the neighborhood knew him and respected him, and he spoke their language". 12 Piscitello came to represent the values of the Italian workers and the goals they sought.

The ethnic physician also serves as a symbolic representative. Lieberson, for example, has shown that the offices of ethnic physicians are located closer to concentrations of their own respective ethnic groups than to any other population in the city of Chicago. The ethnic background of a physician is a handicap in dealing with non-group patients but is not (or is a lesser handicap) in dealing with patients of the same ethnic group.13 In fact, it may be an advantage. As Hall pointed out in an earlier study, the physician's clientele is one of the important sources of the medical role. The doctor comes to realize that his patients expect him to behave in specific ways; and to some degree, he must live up to these expectations. 14 Furthermore, patients rarely consider the doctor's training or ability in choosing a physician. Rather, choices are made on the basis of such irrational things as loyalty, fashion, and prestige. Accordingly, the physician must learn what to base his appeal on. One alternative is to base his appeal on ethnic sentiments. $15 \mathrm{He}$ may present himself as one of the group, practicing and perhaps even living among the ethnic population. Yet if in such a situation he is to develop an ethnic clientele, he must offer something more than medical advice or geographical convenience. $16 \mathrm{He}$ must demonstrate the auxiliary traits which his group values: for example, speaking their language and practicing "the kind of medicine" which they define as appropriate. 
The symbolic representative of an ethnic group is not, however, merely a rallying point: a collection of community values personified. $\mathrm{He}$ is also a symbol of ethnic group prestige and competence in relation to other groups or to society as a whole. 17 His presence contributes to making the group a legitimate, self-sustaining community. Thus, community members do not have to rely on "strangers" - whose competence and sincerity cannot be assured - for medical care. They have their own politicians and labor leaders: people who presumably understand the unique problems of the community and who can be trusted to handle them in the best interests of the community. And they have their own entertainment: musicians who will perform according to the musical taste of the group. Thus, the presence of such occupational statuses within an ethnic community and occupied by members of that community symbolizes both accomplishment and competence. The community is able to provide for itself. Its own members are able to perform these "special" tasks. And thus the ethnic community is put on a more equal footing with other communities.

Marginality and conflict: Due to their requirement of special education and their highly visible character, the occupational statuses which we have been discussing lend themselves more readily to being marginal statuses. And as such, the status incumbents may easily find themselves in positions of confused identity and its accompanying conflicts of loyalty and frustration of personal and group aspirations. 18

Yet another potential conflict is also present. Implicit in these statuses is a technical-specialist function: a commitment to professional goals and procedures or more specifically to organizations and individuals who have served as sponsors. Thus, conflict may arise between the status incumbent's technical-specialist function and his democratic function as a representative or spokesman of the group. 19 While this potential conflict is not unique to these ethnic occupationa statuses, it is more likely to occur in such situations. For example, as a representative, the country musician is expected to provide the sort of musical product which the community desires in order to retain its support. However, the musician's definition of the role as a technicalspecialist may conflict with the public's definition. For example, he may desire to alter his style or instrumentation in a manner rewarding to him as a musician but unappealing to his public as southerners.

The qualifications, personal aspirations, and informal professional creed of the ethnic physician may call for his moving out of the ethnic community and into a modern clinic. Yet he may have to remain in the same old office, perhaps in his home, and refrain from introducing new methods or equipment in order to retain his patients. Hall points out, for example, that for many of the early immigrants, the hospital was defined as a place in which to die and surgery was agreed to only as a last resort. 20 Furthermore, the Italian doctors in his study who moved out of the Italian section and over to the more prestigious East Side were forced to return to the Italian community due to the lack of patients. Thus, while Italians would patronize high prestige non-Italian doctors on the East Side, the moving of an Italian doctor was defined as a breach of solidarity with the ethnic group. 21

The ethnic union leader may also be caught in a conflict between commitment to his administrative duties and commitment to his ethnic group. This commitment varies to a great extent depending on whether the official is appointed or elected. In the former case, he is necessarily dependent on the top leadership while the elected official is understandably more dependent on the membership, often along ethnic lines. 22

The ethnic politician is in a similar position. For him the question may be: Am I a Puerto Rican first and a member of the Democratic Party second, or vice versa? 23

\section{Situationally Defined Behavior}

The behavior of the incumbents of these ethnic occupational statuses is to a large extent situationally determined. Reinforced by his own origin in the ethnic community, the status incumbent is expected to retain many basic traits and values of the ethnic group and to make these evident when in the company of group members. 24 This was implicit in the preceding description of the Italian union leader. To some extent, however, this pertains not only to ethnic leaders but to virtually all union leaders as they seek to represent an occupational group or occupational community. Greer describes it as follows:

In reconciling his managerial position with his members' subordinate place in industry, he uses many tactics. He plays the role of the ordinary member in those organizational interstices where this is possible. His vocabulary and syntax, his common appearances and interests, include those common to his members. He makes a point of personalizing relations with as many members as possible; he tries to be available in person. This is a small part of his make-up kit. ... For the most part, the union leader shares the general point of view of his members, modified only by his different perspective on the organization and the labor movement. (This is another parallel to the race leader's role; he too shares ethnic status, identification, and culture with his followers.) Thus it is difficult to separate these matters, the leader as leader from the leader as working man and union member. 25

Greer goes on to note that since the union leader is often limited in the ability to make policy, his place in the power structure of the union along with the type of local serve as better predictors of behavior than 
knowledge of the official's own ideology. 26

The behavior of the country musician is also determined to a large extent by the situations in which he participates. Thus, while the individual musician may have his own conception of what constitutes good country music, the proper music to record, the proper stage dress and stage manner, his behavior in actuality may be constrained by his position in the social structure of the ethnic-occupational community quite independent of his own beliefs. For example, while the individua country musician may desire to innovate and alter his style, musical arrangements, and instrumentation so as to appeal to the "pop" market, he may be hesitant to do so, for fear of alienating his long-time followers. Furthermore, whether or not most country musicians are actually the sincere, humble, grateful people they purport to be remains an empirical question. However, they do "come on" in this manner And in spite of personality differences, private feuds, or resentment of audience demands, the behavior of the musicians is situationally determined to fulfill a "buddy image".

The Puerto Rican candidate of the Liberal Party for the City Council championed himself as the friend of the dejected ghetto slum dweller and formulated his behavior accordingly. Membership in established political machines is likewise a powerful determinant of behavior. This is reflected in Wakefield's comment:

The motto of the Tony Méndez Club is "I am a Democrat first and a Puerto Rican second", and now it was up to Tony to prove that his people followed the rule. 27

Yet it must be noted that the influence of the situation on behavior has its limits. The candidate for Councilman, for example, explicitly refused to move his family into Spanish Harlem even though he realized that it would cost hin votes.

Examples have already been given describing the manner in which the ethnic physician must alter his behavior - practicing in the ghetto for example - so as to retain his ethnic clientele. The behavior of the doctor who wishes to specialize may also be determined situationally. Barred by the system of sponsorship in the community Hall studied the ethnic physician was constrained to orient his career toward Catholic educational and medical institutions. This, in turn, harnessed the Italian doctor even more to the ethnic-religious community. 28

As has been emphasized, the incumbents of these ethnic occupational statuses are expected to display their identification with their respective "constituents". This is not to say, however, that there is no differentiation between these status incumbents and other members of the ethnic group. Rather, it is the nature of the basic differentiation which makes the identification necessary. The status incumbents are "special" members of the group. They possess scarce talents and occupy positions of potential power, yet power which is contingent upon the consent of the ethnic group. Thus the incumbents must behave according to the expectations of the group. Where personal or professional values conflict with ethnic values, the former must remain undercover.

\section{Summary}

We have used the concept of "auxiliary status traits" to distinguish between general occupational statuses. The latter are general occupational statuses with which auxiliary ethnic traits have come to be associated. But more specifically, they are occupational statuses which share four important characteristics. Thus in the present paper, we have been referring to ethnic service occupational statuses.

Using the occupational statuses of physician (general practitioner), union leader, politician, and musician for the purpose of illustration, we have been exploring some of the career alternatives open to ethnic individuals. Emphasizing the consequences of occupying an ethnic occupational status, we noted that the character of the status is such that the status incumbent serves functions and is confronted with problems which are alien to the non-ethnic incumbent of the general occupational status. Finally, we have discussed the relevance of the ethnic occupational status as a situational determinant of behavior.

\section{FOOTNOTES}

1 Everett C. Hughes, "Social Change and Status Protest: An Essay on the Marginal Man," reprinted in Raymond W. Mack, editor, Race, Class and Power, New York: American Book Company, 1963, p. 290 .

2 In the present paper, "group" and "community" are used in a very general manner. Thus, the community may be restricted to the leve of the big city ghetto, or it may be extended to the national or even international level. However, at the core is an extreme subscription to or identification with the basic values and ideology of an aggregate of ethnic individuals. Thus, there must exist a consciousness or awareness of the similarities among group members. 
3 See Howard S. Becker and James Carper, "The Elements of Identification with an Occupation". American Sociological Review, 21 (June, 1956), pp. 341-348.

4 See Howard S. Becker, Outsiders, Glencoe, Illinois: The Free Press of Glencoe, 1963, p. 82

5 See C. Portis, "That New Sound from Nashville", The Saturday Evening Post, February 12, 1966, pp. 30-38; B. Ellison, "Country Music Is Taking Over", Chicago Sun-Times, February 27, 1966, Section Three, p. 1; S. Dooley, "Roy Acuff, the King of Country Music", Chicago Sun-Times, March 6, 1966, Section Three, p. 1; R. Shelton and B. Goldblatt, The Country Music Story, New York: The Bobbs-Merril Company, Inc., 1966; L. Mennerick, "The Country Music Community", M.A. Paper, Northwestern University, 1966.

6 The jazz musician, for example, does and in fact must reject much of his earlier frame of reference - many of his childhood friends and many of the values which he learned early in life - in order to function as a jazz musician. Because of the complexity of the music, the "squares" do not understand; they do not value the same aspects of music as the jazz musician. Thus, it is not similar racial-ethnic characteristics or values which define the jazz subculture. Rather, it is the sharing of a set of norms, values, and expectations which differ from - and which are to some extent in conflict with - those of the larger culture. See Howard S. Becker, Outsiders, op. cit., pp. 79-119.

7 The Jewish physician, who in Lieberson's study were overrepresented in their ethnic group, attempted to resolve their dilemma by specializing (on the open market). Specialization is advantageous for physicians in their relations with patients who are members of other ethnic groups in that the specialist limits his interaction with the patient to health problems which are his specialty. And due to the rapid turnover of patients, the physician and patient are less likely to become acquainted on an informal basis. Furthermore although specialists in general were more likely than genera practitioners to practice in the prestigious Loop, both Jewish general practitioners and Jewish specialists were more likely to practice in the Loop. This is, in part, presumably a device for status reinforcement. See Stanley Lieberson, "Ethnic Groups and the Practice of Medicine", American Sociological Review, 23 (October, 1958), pp. 547-549.

8 Examples of this within the civil rights movement are numerous. Less well known are promotions such as "Puerto Rican-American Day" and the formation of organizations such as the Country Music Association in Nashville, Tennessee.
9 Scott Greer, Last Man In, Glencoe, Illinois: The Free Press of Glencoe, 1959, p. 160.

10 For example. note the ethnic composition of the two main departments of the Rhode Island General Hospital. Oswald Hall, "The Informal Organization of Medical Practice in an American City", Ph.D. dissertation, University of Chicago, 1944, p. 66.

11 See Dan Wakefield, Island in the City, New York: Corinth Books, Inc., 1957, pp. 249-278.

12 Ibid., p. 210.

13 See Lieberson, op. cit., pp. 544-546.

14 See Hall, op. cit., pp. 114-115.

15 See Ibid., p. 137.

16 As Hall points out, ethnic group membership and close proximity of office location are not guarantees that ethnic group members wil patronize these physicians. Coethnics who are climbing in status may move out of the ghetto or may travel ouside of the ghetto to areas of higher prestige for medical care. See Hall, op. cit., p. 239.

17 For a discussion of a similar phenomenon, see Elena Padilla, $U p$ from Puerto Rico, New York: Columbia University Press, 1958, p. 56.

18 See Hughes, op. cit.

19 This notion is based on one of the two elements of the leadership situation which Greer maintains are common to all union leaders. See Greer, op. cit., pp. 68-69.

20 See Hall, op. cit.,p. 235.

21 See Ibid., p. 167.

22 See Greer, op. cit., p. 159.

23 See Wakefield, op. cit., pp. 249-278.

24 It must be noted, however, that even this is problematic. The ethnic doctor, for example is extremely dependent on the ethnic group's definition of the situation. Thus, their ethnic loyalty may be a great 
asset to him. However, on the other hand, they may define out-group membership as a desirable trait in a doctor. For example, see Padilla, op. cit., pp. 294-295.

25 Greer, op. cit., p. 71.

26 See Ibid., p. 73.

27 Wakefield, op. cit., p. 270.

28 See Hall, op. cit., p. 227.

\section{MARX AND WEBER:}

\section{A THEORY OF HISTORICAL CHANGE}

\section{David Willer \\ University of Kansas}

Though historical sequences of Western civilization are capable of being described by a simple, unilinear, evolutionary theory of history, attempts to generalize unilinear theories beyond Western cultural areas have failed. Thus the attempts of modern "Marxists" to generalize Marx and Engels' "theory of history" beyond its scope of application, Western civilization, have met with the expected results. Their sequence of stages of history simply do not fit other cultural areas. The Marx-Engels theory of history was explicitly designed for a single case and has little or no application outside that case. The theory therefore has no explanatory power and may be viewed as simply a tool for describing a single case. Extension of the theory beyond that case would require modification, specifically conceptual elaboration, such that it becomes more than simply descriptive.

The basis of the stages of the Marx-Engels theory was to be found in the prevailing forms of ownership (or in other words, forms of division of labor). The first historical form was that of "tribal ownership" characterized only by a natural division of labor based on natural differences such as sex and age. In this stage there is no specialized production, and the people support themselves by hunting, fishing, or slash and burn' agriculture.

An increase in population brings about the second form of ownership, "state ownership," the result of the union of several tribes, some tribes becoming slaves to others, and the development of slaves as a means of production. Private property develops in this stage, and the country becomes divided from the city, with power concentrated in the latter. Marx and Engels seem to have had Rome in mind in their description of this stage.

The explanation of the transition from the stage of state property to the apparently more backward stage of feudalism is somewhat elusive. They explain that "Rome indeed never became more than a city; its connection with the provinces was almost exclusively political."1 War, 